\title{
Selection of Postsynaptic Serotonin Receptors During Reinnervation of an Identified Leech Neuron in Culture
}

\author{
Pierre Drapeau and Sergio Sanchez-Armass \\ Neurosciences Unit, Montreal General Hospital Research Institute and Department of Neurology and Neurosurgery, \\ McGill University, Montreal, Quebec H3G 1A4, Canada
}

\begin{abstract}
Serotoninergic Retzius neurons reform an inhibitory synapse onto pressure-sensitive mechanosensory (P) neurons when the cells are removed from the nervous system of the leech and are juxtaposed in tissue culture. The somas of $P$ cells in situ and single (uninnervated) $P$ cells in culture have both a depolarizing and $\mathrm{Cl}$-dependent hyperpolarizing response to application of the transmitter serotonin (5-HT). Synaptic release of 5-HT by a Retzius cell in situ and in culture evokes a Cl-dependent postsynaptic response but does not appear to activate the depolarizing receptors. We have characterized the ionic currents induced by synaptically released and applied 5-HT in voltage-clamped $P$ cells in culture in order to determine the responses to transmitter and their modifications following innervation.
\end{abstract}

When 5-HT was applied to single P cells, 2 types of channels were activated by $5-\mathrm{HT}$ and could be distinguished by changing the ionic composition of the superfusion solution. In an impermeant cation (Tris $\mathrm{Cl}$ ) solution, a 5-HT-dependent $\mathrm{Cl}$ current was activated. When single $\mathrm{P}$ cells were superfused with a $\mathrm{Cl}$-free solution ( $\mathrm{Cl}$ replaced by impermeant $\mathrm{SO}_{4}$ ), 5-HT activated a monovalent cation current.

Following innervation of a P cell by a cocultured Retzius cell, the reversal potential of the peak postsynaptic current depended on the $\mathrm{Cl}$ gradient and the synaptic response was blocked by the $\mathrm{Cl}$ channel blocker 9-anthracenecarboxylic acid. Thus, synaptic release of 5-HT activated solely the $\mathrm{Cl}$ channels and not the cationic channels. Pipette application of 5-HT onto innervated $P$ cells activated a $\mathrm{Cl}$ conductance comparable in magnitude to the synaptic response. In contrast, the cationic conductance was reduced roughly 5-fold. It is concluded that innervation of a P cell by a Retzius cell resulted in clustering of the synaptic 5-HT receptors, which activate $\mathrm{Cl}$ channels and reduction of the nonsynaptic, cationic response. The result is a selection of receptors in the cultured $\mathbf{P}$ cell that mimics the pattern observed in vivo.

\footnotetext{
Received Jan. 21, 1988; revised Apr. 1, 1988; accepted May 16, 1988.

We thank Mr. George Ferguson for his help with computer programming and Mr. Jean-Marie Clairoux for his skillful assistance in preparing the cultures. S.S. A. was supported as a Visiting Scientist by the MRC of Canada, the FCAR du Québec and the Research Institute of the Montreal General Hospital. P.D. was supported by grants and scholarships from the MRC of Canada and the FRS du Québec.

Correspondence should be addressed to Dr. Pierre Drapeau, Department of Neurology, Montreal General Hospital, 1650 Cedar Avenue, Montreal, Quebec, Canada H3G 1 A4.
}

Copyright (C) 1988 Society for Neuroscience $0270-6474 / 88 / 124718-10 \$ 02.00 / 0$
Ionic channels in excitable cells are often differentially distributed over the cell surface (Hille, 1984). A striking example is the clustering of ACh receptors in skeletal muscle cells (Fambrough, 1979) and in parasympathetic neurons of the frog (Harris et al., 1971), where receptor density is increased by several orders of magnitude at the postsynaptic regions. In contrast to the detailed information about muscle cells, little is known about changes in neuronal receptors during synapse formation in the CNS. In the few detailed studies carried out to date, transmitter receptors have been observed to appear or disappear in identified neurons at different developmental stages (Goodman and Spitzer, 1979; Bixby and Spitzer, 1982).

Studies of identified invertebrate neurons have shown that a cell can have multiple types of receptors for a particular transmitter (Gerschenfeld, 1973), yet often only a single receptor type is activated at subsynaptic sites (Gerschenfeld and Paupardin-Tritsch, 1974). An example is the pressure-sensitive mechanosensory $(\mathrm{P})$ neuron of the leech. Both depolarizing and Cl-dependent hyperpolarizing responses are observed upon application of serotonin (5-HT) to the P cell soma (Henderson, 1983). Synaptic release of 5-HT from a Retzius cell evokes Cldependent inhibitory synaptic potentials in the $\mathrm{P}$ cell but does not appear to activate the depolarizing receptors (Fuchs et al., 1982). The physiological role of the depolarizing response has not been determined.

How the sorting of postsynaptic receptors comes about during development is unknown. Obstacles to studies in the CNS include the inaccessibility and small size of synapses. In order to simplify the study of synapse formation, identified leech neurons have been removed from the CNS and grown in tissue culture, where they reform specific synapses when paired with appropriate partners (Ready and Nicholls, 1979). Cultured Retzius cells from the leech reform the inhibitory synapse with $P$ cells as demonstrated by anatomical, biochemical, and physiological criteria (Nicholls, 1987). The synaptic potentials recorded in the $P$ cell are reversed by increasing the intracellular $\mathrm{Cl}$ level using a $\mathrm{KCl}$ electrode (Fuchs et al., 1982). However, the properties of the synaptic response-such as the ionic selectivity, kinetics, and, more importantly, the relative contributions of the 2 types of 5-HT-activated channels-have not been determined.

An important technical advantage of the cultured neurons is the ability to record accurately synaptic interactions using the voltage-clamp technique (Dietzel et al., 1986). We have characterized the ionic currents in voltage-clamped $P$ cells in response to applied and synaptically released transmitter during synapse formation. Innervation of the $\mathbf{P}$ cell in culture is shown to activate solely a $\mathrm{Cl}$ conductance and to markedly reduce a 


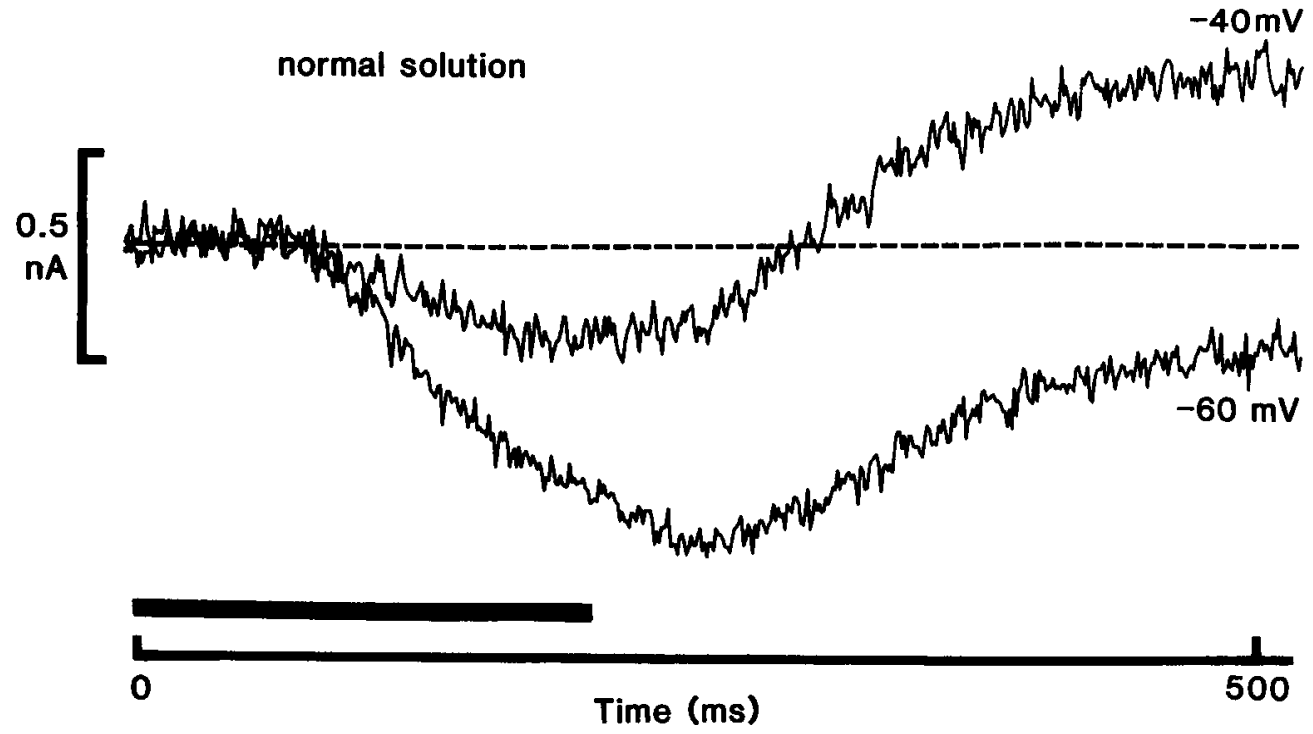

Figure 1. Currents activated by application of 5-HT onto a single P cell in culture. The $P$ cell was superfused in normal solution and voltage-clamped at $-40 \mathrm{mV}$ (upper trace) and at -60 $\mathrm{mV}$ (lower trace). 5-HT, $100 \mu \mathrm{M}$, dissolved in the same solution was applied for the $200 \mathrm{msec}$ period indicated by the dark bar. The current traces were superimposed at the beginning of the records, and the baseline is indicated by the broken line. nonsynaptic monovalent cation conductance, resulting in a redistribution of responses to 5-HT resembling that observed in vivo. A brief report of some of these results has been published elsewhere (Drapeau and Sanchez-Armass, 1987).

\section{Materials and Methods}

Cultures. Retzius and P cells were isolated from the nervous system of the leech Hirudo medicinalis and cultured as described previously (Dietzel et al., 1986). Desheathed ganglia were exposed to collagenase (Type XI, Sigma Chemical Co., St. Louis) and the somas of the easily identified Retzius and $P$ neurons were removed by aspiration into a micropipette. The cells were plated singly or in pairs in the wells of polylysine-coated microtest culture dishes containing Leibovitz- 15 medium supplemented with $2 \%$ heat-inactivated fetal bovine serum (Gibco Canada, Burlington, Ontario, Canada). Under these conditions, the cells usually did not extend neurites (better for voltage clamping-see Dietzel et al., 1986) and formed synapses after Retzius and $P$ cell somas were juxtaposed during plating. Most experiments were performed 7-10 d after plating.

Recordings. Retzius and $\mathbf{P}$ cells in culture were easily distinguished by their different sizes, by their positions following plating in the culture dishes and by their characteristic electrical properties which are retained in culture (Fuchs et al., 1981). Presynaptic action potentials were triggered in Retzius cells by passing current through the recording microelectrode ( $4 \mathrm{M} \mathrm{K}$ acetate) using a bridge circuit. $P$ cells were voltageclamped by impalement with a single microelectrode ( 4 M Cs acetate, except for the experiment in Fig. $8 B$, where a CsCl electrode was used; 15-20 m $\Omega$ ) using a sample-and-hold amplifier (Axoclamp 2a, Axon Instruments, Burlingame, $\mathrm{CA}$ ) operating at switching rates of $2-5 \mathrm{kHz}$. When superfused with solutions containing impermeant ions (see below), the cells were held at a potential of $0 \mathrm{mV}$ for 3-5 min before beginning the experiment in order to reduce the leak current, presumably by replacement of intracellular cations by relatively impermeant $\mathrm{Cs}$ in the electrode (see Fig. 2). The holding potential was maintained within $1 \mathrm{mV}$ of the command voltage during the slow 5-HT-activated current fluctuations recorded in these experiments and resulted in $<5 \%$ underestimate of the peak synaptic currents. Reproducible responses could be recorded for up to half an hour in the solutions containing impermeant ions and for longer periods in normal solution or in culture medium, e.g., during recordings of synaptic currents. The current signals were low-pass-filtered (1-pole Bessel filter, $-3 \mathrm{~dB}$ at $0.3 \mathrm{kHz}$ ), and digitized data were acquired at a frequency of $1 \mathrm{kHz}$ and analyzed with an LSI-1 1/73 computer (Digital Equipment Corp., Maynard, MA) and an INDEC Systems interface (Sunnyvale, CA) and stored on a hard disk. Peak current values were calculated from the difference between the 50 msec baseline ( 50 points \pm SE) immediately before eliciting a response and the 5-point peak $\pm S E$ (for synaptic responses) or the 10-point peak \pm SE (for pipette applications).

The recordings were made while the cells were continually superfused in media of the following composition (in $\mathrm{mm}$ ) (all solutions were adjusted to $330 \mathrm{mOsm} / \mathrm{liter}$ and to $\mathrm{pH} 7.4$ ): normal solution: $\mathrm{NaCl}, 165$; $\mathrm{KCl}, 5 ; \mathrm{MgCl}_{2}, 1 ; \mathrm{CaCl}_{2}, 10$; glucose, 10; HEPES, 10; TrisCl solution: TrisCl, 165; CsCl, 5; $\mathrm{CoCl}_{2}, 3 ; 3$,4-diaminopyridine (DAP), 10; glucose, $10 ; \mathrm{Na}+\mathrm{KSO}$ solution: $\mathrm{Na}_{2} \mathrm{SO}_{4}, 130 ; \mathrm{K}_{2} \mathrm{SO}_{4}, 4 ; \mathrm{MgSO}_{4}, 5 ; \mathrm{DAP}, 10$; glucose, 10; 9-anthracenecarboxylic acid (9-AC), $0.1 \mathrm{~mm}$ from a $0.1 \mathrm{M}$ stock solution dissolved in methanol; HEPES, 10; TrisSO ${ }_{4}$ solution: $\mathrm{Tris}_{2} \mathrm{SO}_{4}, 140 ; \mathrm{MgSO}_{4}, 5$; DAP, 10 ; glucose, 10; 9-AC, 0.1; other solutions in which one ingredient was excluded (DAP), substituted (Ca or $\mathrm{Mg}$ ) or added $[0.1 \% \mathrm{vol} / \mathrm{vol}$ of $0.1 \mathrm{M}$ stock solutions of cyproheptadine (CYP) or 4-stilbene isothiocyanato-2,2'-disulfonic acid (SITS) dissolved in methanol] are indicated in the text and figure legends.

5 -HT was applied by pressure ejection ( $200 \mathrm{msec}$ pulse at $1 \mathrm{bar}$ ) from a large-diameter $(15-20 \mu \mathrm{m})$ pipette containing $100 \mu \mathrm{M}$ 5-HT dissolved in the same solution used to superfuse the cells. In a preliminary study, the nontoxic dye Fast green ( $0.2 \%$ ) (Sigma) was added to the solution used to fill the pressure pipette. It was easy to position the pipette consistently such that the puff of ejected dye engulfed the cell without moving it. When $\mathrm{KCl}$ was added to the solution with which test pipettes were filled, a step depolarization was observed coincident with the pressure pulse. The rapid removal of ejected solutions during continual superfusion $(100 \mu \mathrm{l} / \mathrm{min})$ of the cells in the $10 \mu \mathrm{l}$ wells prevented desensitization of the responses. 5-HT, $100 \mu \mathrm{M}$, gave reproducible maximal responses and was the concentration used in all experiments reported here (unless stated otherwise), although the 5-HT concentration at the cell must have been lower than in the pipette. The kinetics of the very slow effects of ejected 5-HT observed in this study depended somewhat on the flow around each cell, resulting in slightly variable time courses for the induced current changes.

\section{Results}

\section{Single $P$ cell}

When a single voltage-clamped $P$ cell in culture was superfused with normal solution (containing $\mathrm{Na}, \mathrm{K}, \mathrm{Ca}, \mathrm{Mg}$, and $\mathrm{Cl}$ ), depolarization activated a large, transient, voltage-dependent $\mathrm{Na}$ conductance that generated action potentials and was poorly compensated by the single electrode clamp (not shown). However, a new steady-state conductance (partially dependent on $\mathrm{Na}$ ) was reached within $100 \mathrm{msec}$ following a change in the holding potential. After the $\mathbf{P}$ cell had reached a steady current level, pressure ejection of $100 \mu \mathrm{M}$ 5-HT activated a change in current that depended on the holding potential (see Fig. 1). At potentials hyperpolarized from the normal resting potential of the $P$ cell in culture ( $-50 \mathrm{mV}$; Fuchs et al., 1981), a transient inward current was recorded. Because of the continuous superfusion of the cells, the responses to 5-HT did not densensitize. 
Figure 2. Effect of ion substitution on a single $P$ cell in culture. The steadystate (leak) current was determined in a single $P$ cell in culture held at the potentials indicated in the $I-V$ plot, while the $P$ cell was superfused with normal solution (open circles), TrisCl solution (filled circles), or TrisSO $\mathrm{S}_{4}$ solution (diamonds).

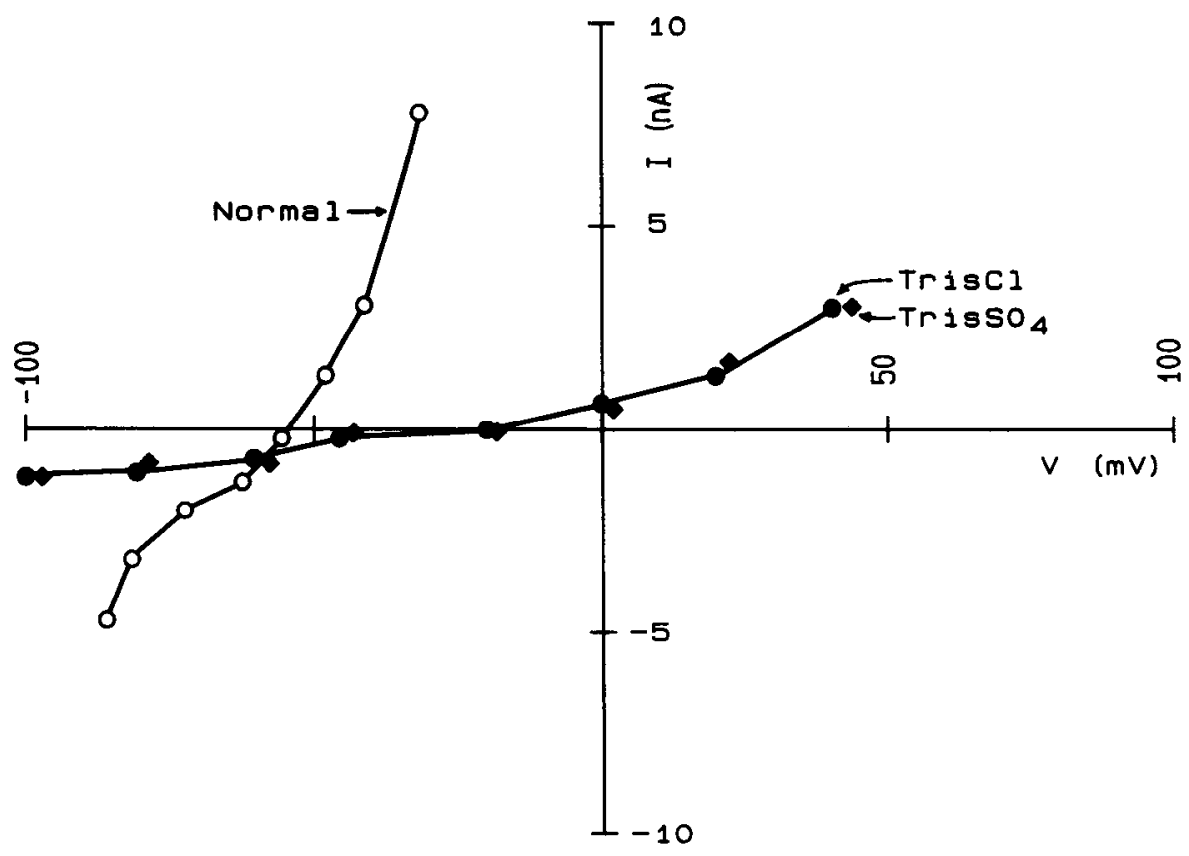

Although the response to 5-HT (maximal at $100 \mu \mathrm{M}$ ) was similar for different $\mathbf{P}$ cells, the time course of the responses varied slightly with pipette position (see Materials and Methods).

At potentials depolarized from the resting level, a later, outward current was also observed. These current changes account

for the fast depolarizing and slow hyperpolarizing responses observed previously for the $\mathrm{P}$ cell in culture and in vivo (Henderson, 1983). As described below, 2 components of the 5-HTactivated current could be distinguished by differences in ionic selectivity and sensitivity to channel blockers: a Cl conductance

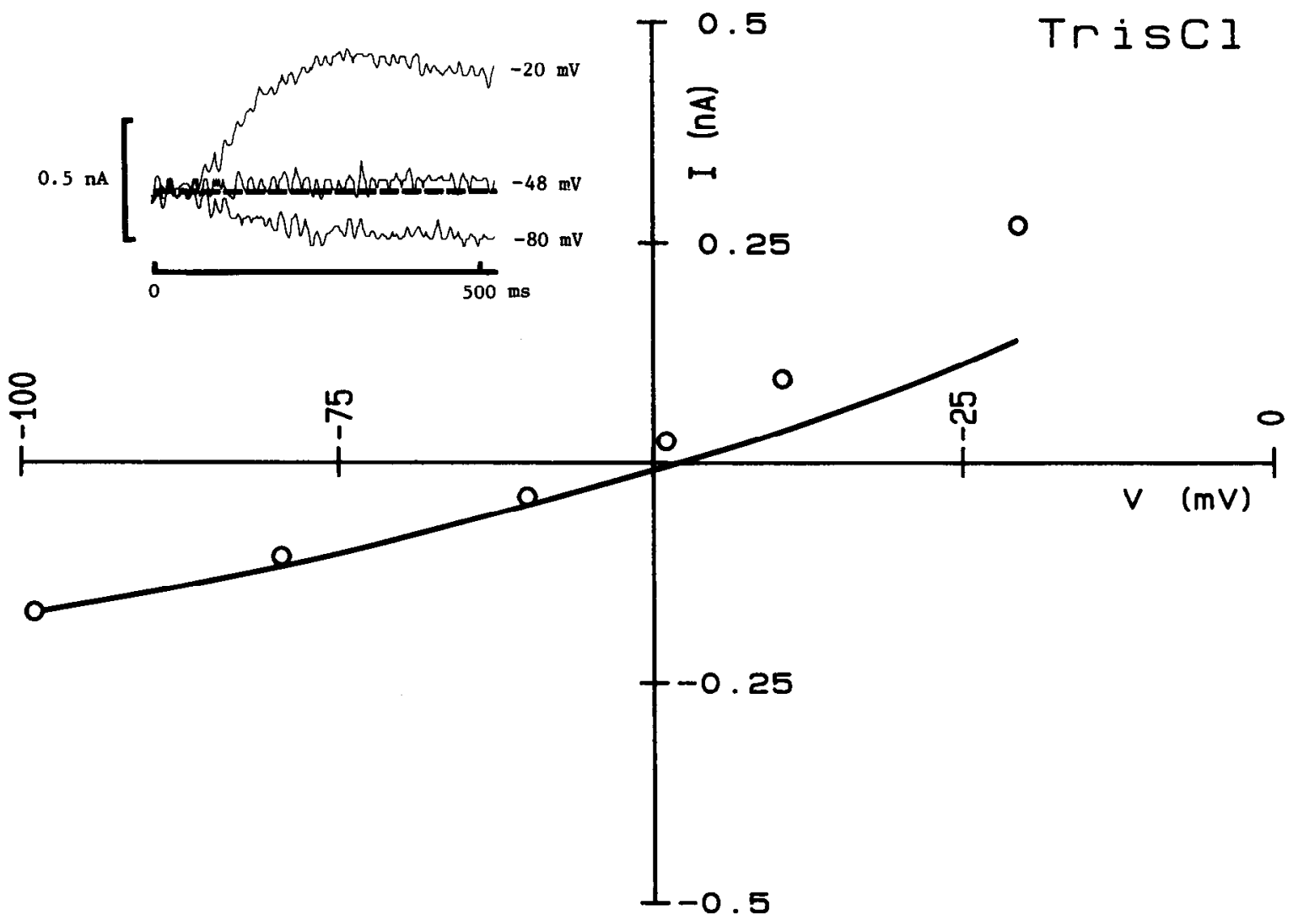

Figure 3. $I-V$ relationship for $g \mathrm{Cl}_{\mathrm{s}}$ in a single $\mathrm{P}$ cell in culture. A single $\mathrm{P}$ cell was superfused with TrisCl solution and held at the indicated potentials, while $100 \mu \mathrm{M} 5$-HT dissolved in the same solution was applied from a pipette for a $200 \mathrm{msec}$ period. The peak current is plotted as a function of the holding potential (circles). The line is the solution to the constant field equation: $I=k_{1} \times\left[\mathrm{Cl} l_{i} \times \exp \left(k_{2}\right)-\mathrm{Cl} l_{0} /\left[\exp \left(k_{2}\right)-1\right]\right.$, where $\mathrm{Cl}_{\mathrm{o}}=175 \mathrm{mM}, \mathrm{Cl}_{\mathrm{i}}=26 \mathrm{mM}$ (for current reversal at $-48 \mathrm{mV}$ ), $k_{1}$ is equal to the permeability of $\mathrm{Cl} \times Z^{2} F^{2} V / R T, k_{2}=Z F V / R T$ and $Z, F, V, R$, and $T$ have their usual meanings. 
TrisCl

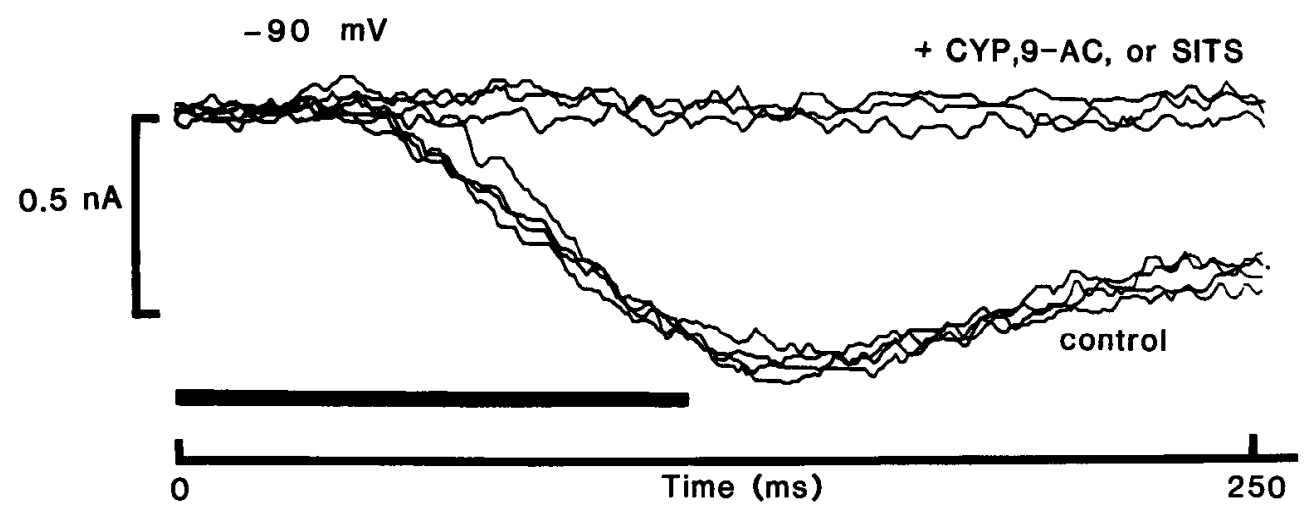

Figure 4. Effect of blockers on $\mathrm{gCl}_{\mathrm{S}}$ in a single $P$ cell in culture. A single $P$ cell was superfused in $\mathrm{Tris} C \mathrm{Cl}$ solution and held at $-90 \mathrm{mV}$. In the first trace (control), 5-HT was applied from a pipette for the period indicated by the dark bar. The superfusion solution was then switched for one containing $100 \mu \mathrm{M}$ of either CYP, 9-AC, or SITS and 5-HT was applied $\sim 30 \mathrm{sec}$ later. The $\mathrm{P}$ cell was then superfused with drug-free (control) TrisCl solution and a test pulse of 5-HT was applied. In other words, the 4 control traces are before application of the drug with washes between each drug and a final trace after the last drug. $\left(g \mathrm{Cl}_{\mathrm{s}}\right)$ and a monovalent cation conductance $\left(g \mathrm{gation}_{\mathrm{s}}\right)$, neither of which were observed in the absence of 5-HT.

5-HT-activated $\mathrm{Cl}$ conductance $\left(\mathrm{gCl}_{\mathrm{S}}\right)$. When a single $\mathrm{P}$ cell was superfused in $\mathrm{TrisCl}$ solution (impermeant cations: $\mathrm{Na}$ replaced by Tris, $\mathrm{K}$ by $\mathrm{Cs}, \mathrm{Ca}$ by $\mathrm{Co}$, and DAP added), the input resistance of the cell increased by 10-20-fold (compare open and filled circles, Fig. 2). The steady-state (leak) $I-V$ relationship for the $P$ cell showed a small outward rectification at depolarized potentials, probably due to incomplete block of the $\mathrm{K}$ current. When $\mathrm{Cl}$ was replaced by impermeant $\mathrm{SO}_{4}$ in the solution used to superfuse the same $P$ cell (diamonds in Fig. 2), we detected no change in the $I-V$ relationship, indicating that the $\mathrm{P}$ cells lacked a measurable leak conductance to $\mathrm{Cl}$.
When 5-HT was applied from a pressure pipette, an inward current was observed at hyperpolarized potentials and reversed at $-48 \pm 3 \mathrm{mV}(n=7)$ (see inset, Fig. 3). The peak $I-V$ relationship of the response to 5-HT (plotted in Fig. 3) consistently displayed a slight outward rectification beyond that predicted by the constant field equation (Goldman, 1943; Hodgkin and Katz, 1949; solid line in Fig. 3 for a current reversing at -48 $\mathrm{mV}$ ). In order to test for the specificity of the 5-HT effect, $\mathrm{P}$ cells were superfused with $\mathrm{Tris} C \mathrm{C}$ solution or with solution containing $100 \mu \mathrm{M}$ of the 5-HT antagonist CYP (Sawada and Coggeshall, 1976). As shown in Figure 4, CYP reversibly blocked the current activated by 5-HT. Figure 4 also shows current recordings from the same $\mathrm{P}$ cell when superfused with $\mathrm{TrisCl}$

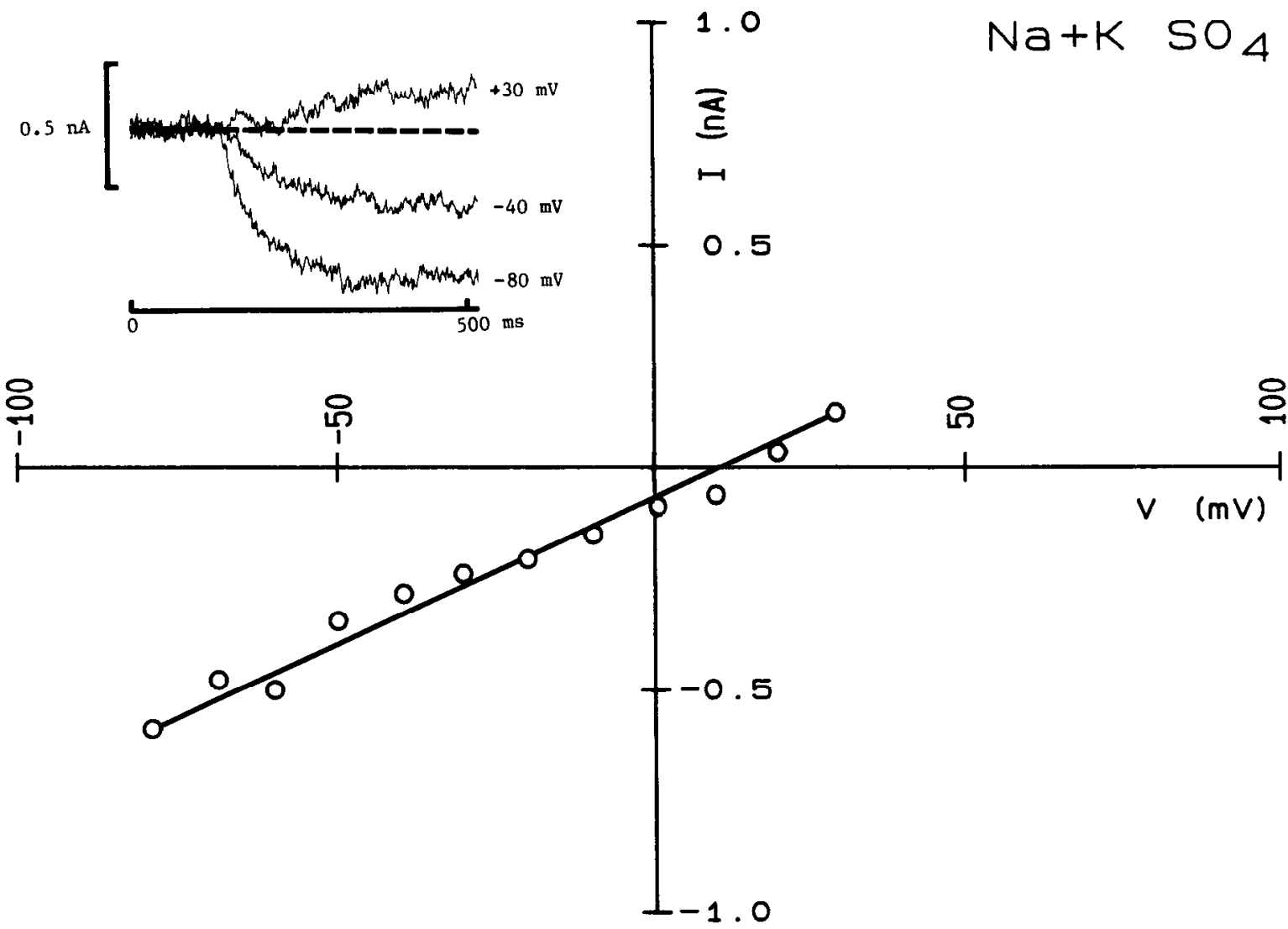

Figure 5. $I-V$ relationship for $g$ Cation $_{\mathrm{S}}$ in a single $\mathrm{P}$ cell in culture. A single $\mathrm{P}$ cell was superfused with $\mathrm{Na}+\mathrm{K} \mathrm{SO}_{4}$ solution and held at the indicated potentials while $100 \mu \mathrm{M} 5$-HT dissolved in the same solution was applied from a pipette for a 200 msec period. The peak current is plotted as a function of the holding potential (circles) and the straight line was fitted by eye. 
Figure 6. Effect of blockers on gCation in a single $P$ cell in culture. $A$ single $\mathbf{P}$ cell was superfused in $\mathrm{Na}+\mathrm{K} \mathrm{SO}_{4}$ solution (containing 9-AC) and was held at $-60 \mathrm{mV}$ while $5-\mathrm{HT}$ was applied from a pipette for the period indicated by the dark bar. The superfusion solution was then switched for one containing $100 \mu \mathrm{M}$ CYP and 5-HT was applied. Following superfusion with solution containing CYP, the $P$ cell was superfused with CYP-free (control) $\mathrm{Na}+\mathrm{K} \mathrm{SO}_{4}$ solution and a test pulse of 5-HT was applied.
$-60 \mathrm{mV} \quad \mathrm{Na}^{-K \mathrm{SO}_{4}}$

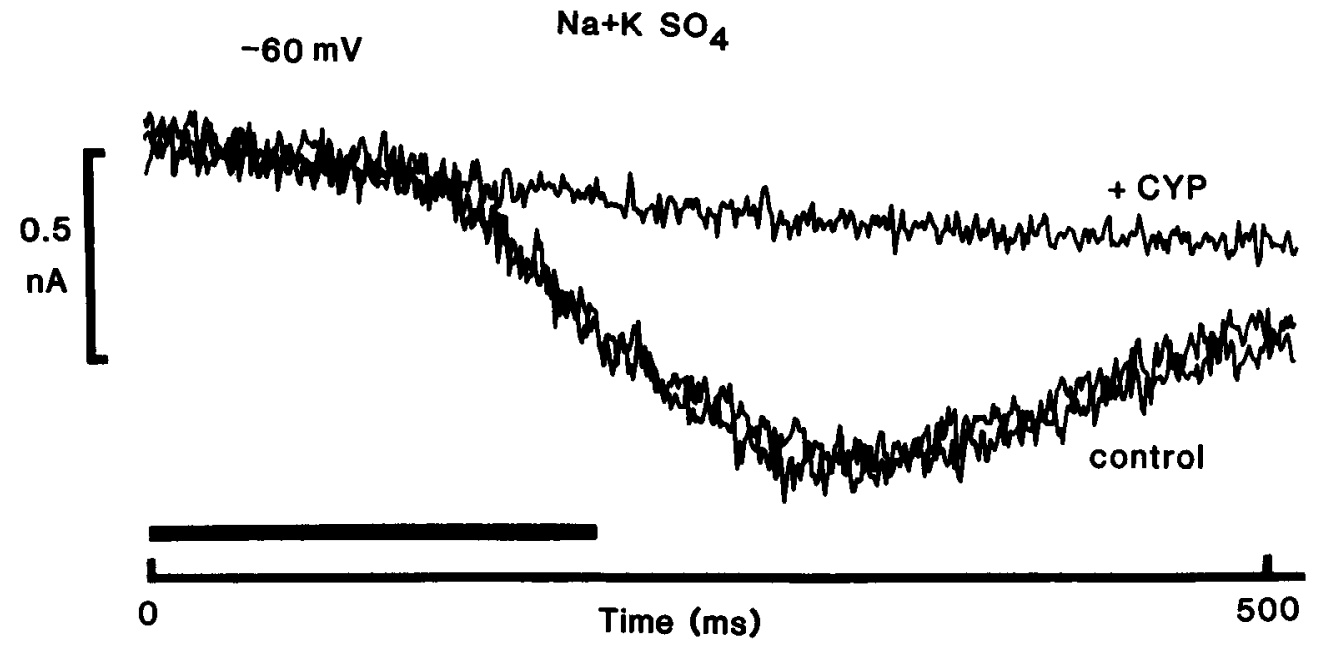

solution containing $100 \mu \mathrm{M}$ of the $\mathrm{Cl}$ channel blockers 9-AC (Bryant and Morales-Aguilera, 1971) or SITS (Knauf and Rothstein, 1971). These compounds also reversibly blocked the 5-HTactivated current. Taken together, these data indicate that 5-HTactivated a $\mathrm{Cl}$ conductance $\left(g \mathrm{Cl}_{\mathrm{s}}\right)$, consistent with previous recordings of $\mathrm{Cl}$-dependent voltage responses in this cell upon 5-HT application in situ and in culture (Henderson, 1983). The similarity of the reversal potential for the $\mathrm{Cl}$ current and the resting potential of the $\mathrm{P}$ cell suggests that $\mathrm{Cl}$ is distributed passively in this cell and, as discussed above, is relatively impermeant in the absence of 5-HT.

5-HT-activated monovalent cation conductance (gCations $s_{s}$ ). When 5-HT was applied to single $\mathrm{P}$ cells in culture superfused with $\mathrm{Na}+\mathrm{K} \mathrm{SO}_{4}$ solution ( $\mathrm{Cl}$ replaced by impermeant $\mathrm{SO}_{4}$ and 9-AC included, Ca substituted by $\mathrm{Mg}$, DAP added), an inward current was activated at hyperpolarized potentials and reversed at $5 \pm 4 \mathrm{mV}(n=9)$ (see inset to Fig. 5). The peak $I-V$ relationship for the 5-HT response was linear (open circles, Fig. 5). Replacing $\mathrm{Mg}$ by $\mathrm{Ca}$ did not affect the 5-HT-activated current (not shown), indicating that 5-HT activated a monovalent cation conductance $\left(g\right.$ Cation $\left._{s}\right)$. Since the reversal potential for $g$ Cation is between that expected for $\mathrm{K}$ and $\mathrm{Na}$ ions in the $\mathrm{P}$ cell, we conclude that the channel is relatively nonselective for monovalent cations and is impermeable to divalent ions.

Including $100 \mu \mathrm{M}$ CYP in the superfusion solution resulted in reversible block of $g$ Cation $_{\mathrm{S}}$ (Fig. 6; note that the baseline is drifting, i.e., first $100 \mathrm{msec}$ or so), supporting the specificity of the 5-HT dependence of this receptor. 9-AC had no effect on the current elicited in $\mathrm{Na}+\mathrm{K} \mathrm{SO}_{4}$ solution (present in the superfusion solutions used in Fig. 6), as expected for activation by 5-HT of a cationic current (as opposed to effux of $\mathrm{Cl}$ via the $\mathrm{Cl}$ channel). When $\mathrm{P}$ cells were superfused with $\mathrm{TrisSO}_{4}$ solution (containing 9-AC) and were held at hyperpolarized potentials, 5-HT failed to activate a current in 2 experiments and elicited only a small outward current in 3 other experiments (data not shown), consistent with 5-HT activation of a cationic conductance.

\section{Synaptic responses in innervated $P$ cells}

Retzius cells innervated juxtaposed $P$ cells in culture. Triggering an action potential in the presynaptic neurons evoked a postsynaptic current in the $P$ cell with a direction and magnitude that depended on the holding potential (inset, Fig. 7). As shown in the plot of the peak synaptic $I-V$ relationship (filled circles, Fig. 7), the synaptic current was inward at hyperpolarized potentials, reversed at $-50 \pm 2 \mathrm{mV}(n=15)$ and showed outward rectification. Figure 7 includes the values (open circles) and constant field theory prediction (solid line) for the $I-V$ relationship for $g \mathrm{Cl}_{\mathrm{s}}$ shown in Figure 3, scaled to overlap with the synaptic data (filled circles). The voltage dependence of the peak synaptic and 5-HT-activated $\mathrm{Cl}$ currents are similar. We therefore examined the ionic dependence of and effects of $\mathrm{Cl}$ channel blockers on the synaptic currents.

Figure $8 A$ shows the peak synaptic $I-V$ relationship of a $\mathrm{P}$ cell superfused in normal $(175 \mathrm{~mm} \mathrm{Cl})$ solution before (open circles) and after (filled circles) superfusing the cells with a low (15 mM) $\mathrm{Cl}$ solution ( $\mathrm{Cl}$ substituted by $\mathrm{SO}_{4}$; diamonds). The solid lines are the solutions to the constant field equation for a $\mathrm{Cl}$ current reversing at $-50 \mathrm{mV}$ in normal solution (upper line) and recalculated for the lower $\mathrm{Cl}$ concentration (lower line). Changing the external $\mathrm{Cl}$ concentration resulted in a predictable shift of the peak $I-V$ relationship. A similar experiment was performed with other innervated $\mathrm{P}$ cells using a $\mathrm{CsCl}$ electrode in order to raise intracellular $\mathrm{Cl}$. This also resulted in an upfield shift of the peak $I-V$ relationship (open circles, Fig. $8 B$ ) that was more pronounced when the $\mathrm{Cl}$ gradient was increased further by lowering extracellular $\mathrm{Cl}$ (diamonds, Fig. 8B). These results are consistent with synaptic activation of $g \mathrm{Cl}_{S}$ and account for previous observations of the effect of changing the $\mathrm{Cl}$ gradient on synaptic potentials in the $\mathrm{P}$ cell in culture and in situ (Fuchs et al., 1982).

The $\mathrm{Cl}$ channel blocker 9-AC (Fig. 9A) and the 5-HT antagonist CYP (Fig. 9B) both blocked the synaptic current. However, it took several minutes of superfusion with either of these agents before the block was complete, and only partial recovery was observed upon washout, contrasting with the far more rapid and reversible effects described above for single $P$ cells. A synaptic diffusional barrier might account for this result, particularly since synapses often form along Retzius cell fingers that invaginate the P cell soma (Kuffler et al., 1987).

In 20 experiments, we determined the peak synaptic $I-V$ relationship, measured the effects of altering the $\mathrm{Cl}$ gradient on this relationship, or tested for complete current blockage during superfusion with 9-AC. The results demonstrated that the synaptic currents were due solely to activation of $\mathrm{gCl}_{\mathrm{S}}$ and werc independent of gCation $_{\mathrm{s}}$ (see Fig. 12). 


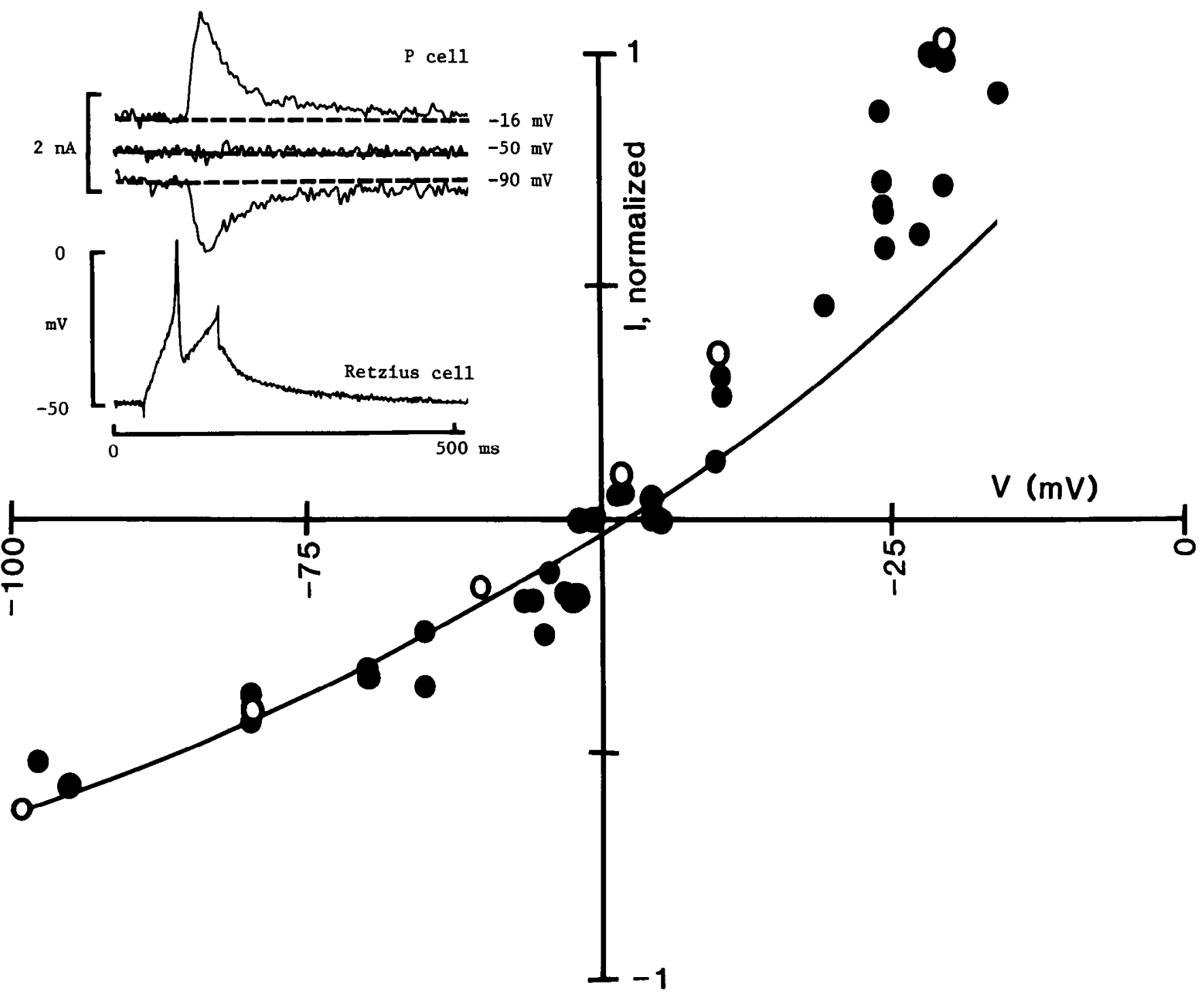

Figure 7. Synaptic currents in a single $\mathrm{P}$ cell in culture. A P cell innervated by a Retzius cell was held at the indicated potentials, and the current evoked by triggering an action potential in the Retzius cell was recorded (see inset). The peak synaptic current is plotted as a function of the holding potential (filled circles) and is normalized so that the maximum current (i.e., 1 on the scale) is $2.2 \mathrm{nA}$. The open circles and line are the data and constant field relationship for $\mathrm{gCl}_{\mathrm{s}}$ shown in Figure 3 and are scaled so that the maximum current is $0.25 \mathrm{nA}$.

We examined in greater detail the decay of $g \mathrm{Cl}_{\mathbf{s}}$ following synaptic release of 5-HT from a Retzius cell in order to understand better the kinetic properties of the $\mathrm{P}$ cell $\mathrm{Cl}$ channel. The time course of the decay of the synaptic currents recorded in the experiment shown in Figure 7 (the largest response observed) was examined as shown in Figure 10. The decay of the synaptic current was inadequately described by a single-exponential function (broken line fitted by eye in Fig. 10) and was better fit by a biexponential time course (solid line fitted by regression analysis, Fig. 10) with time constants that averaged approximately 70 and $600 \mathrm{msec}$ over the voltage range examined $(-100$ to $-10 \mathrm{mV}$ ). Although the values obtained for the time constants showed considerable scatter (inset, Fig. 10), the rate of synaptic decay appeared to be independent of the holding potential. The apparent voltage independence of the 2 time constants for the decay of the synaptic current suggests that the outward rectification of the $\mathrm{Cl}$ channels was due to the permeation mechanism rather than to gating. The dual timc constants could have been due to separate processes for closing of the channel or to sub- classes of channels closing at different rates. Whichever case applies, the similarity of the $I-V$ relationships for both synaptically and pipette-released 5-HT suggests that the same $\mathrm{Cl}$ conductance was activated, i.e., that the channels are present on the somas of single $P$ cells and on the somas and at postsynaptic sites of innervated $P$ cells.

\section{Responses of innervated $P$ cells to applied 5-HT}

We examined the extent of the modification of the responses to 5-HT in innervated P cells by comparing the magnitudes of the synaptic conductances and the conductances activated by application of 5-HT from a pipette. As shown in Figure 11, innervated $\mathrm{P}$ cells retained $\mathrm{gCl}_{\mathrm{S}}$ (upper-right-hand trace) but had a greatly reduced $g_{\text {Cation }}$ (lower-right-hand trace). The results from this series of experiments are summarized in Figure 12. When 5-HT was applied from a pipette, $g \mathrm{Cl}_{\mathrm{s}}$ was reduced by half in innervated $\mathrm{P}$ cells and synaptically activated $g \mathrm{Cl}_{\mathrm{S}}$ was lower (but not significantly) when the results were compared with the data for single $P$ cells. 
A

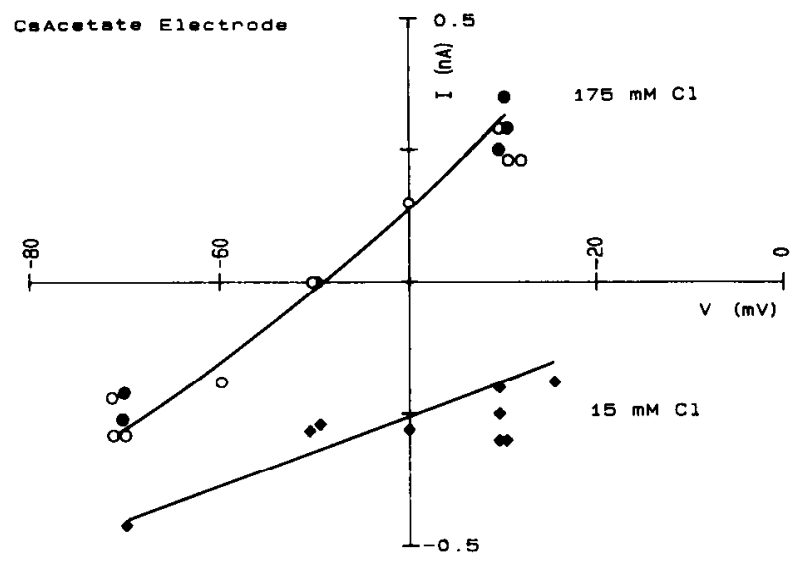

B

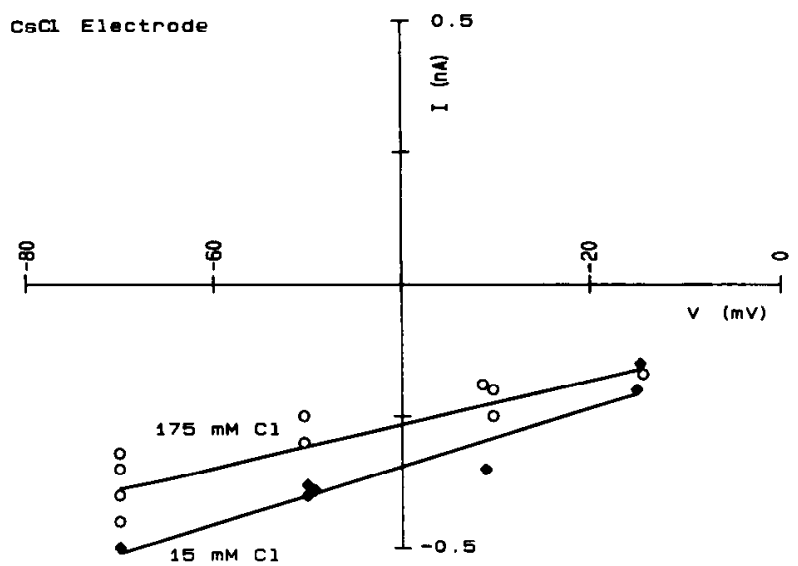

Figure 8. Effect of the $\mathrm{Cl}$ gradient on synaptic currents in the $\mathbf{P}$ cell in culture. $\mathbf{P}$ cells innervated by Retzius cells were held at the indicated potentials, and the current evoked by triggering an action potential in the Retzius cell was recorded. $A$, Peak synaptic current plotted as a function of the holding potential at the beginning of the experiment (open circles), after switching the superfusion solution for one in which most of the $\mathrm{Cl}$ was substituted by $\mathrm{SO}_{4}$ (diamonds), and at the end of the experiment in normal solution (filled circles). The lines are solutions to the constant field equation (see legend to Fig. 3) for $\mathrm{Cl}_{\mathrm{o}}=175 \mathrm{mM}$ (upper line) and $\mathrm{Cl}_{\mathrm{o}}=15 \mathrm{~mm}$ (lower line). $B$, A similar experiment was performed with a $\mathrm{P}$ cell using a $\mathrm{CsCl}$ eletrode in order to increase $\mathrm{Cl}_{\mathrm{i}}$. The circles represent data obtained while superfusing the cell in normal solution, and the diamonds are results obtained in a solution with most of the $\mathrm{Cl}$ substituted by $\mathrm{SO}_{4}$. The solid lines were drawn by eye.

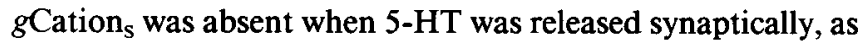
described above. When tested by application of 5-HT from a

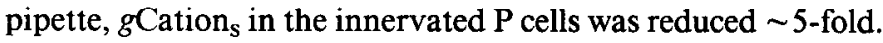

\section{Discussion}

$P$ cells in culture had 2 types of 5-HT receptors that were blocked by the 5-HT antagonist CYP: one that activated a $\mathrm{Cl}$ channel that did not contribute to the resting conductance and a second type that activated a nonselective monovalent cation channel. Activation of both $\mathrm{gCl}_{\mathrm{s}}$ and $g$ Cation $_{\mathrm{S}}$ accounts for the voltage responses observed when 5-HT is applied onto the $\mathrm{P}$ cell in culture and in situ (depolarization and Cl-dependent hyperpolarization; Henderson, 1983).
Synaptically activated $g \mathrm{Cl}_{\mathrm{s}}$ in innervated $\mathrm{P}$ cells was similar in magnitude to $\mathrm{gCl}_{\mathrm{S}}$ measured in single $\mathrm{P}$ cells. In a previous study, we have shown that synapses are formed at regions of contact between the somas of the cells and along short fingers of the Retzius cell that invaginate the $P$ cell soma (Kuffler et al., 1987). The area of the synaptic sites amounts to only a few square microns of the $\sim 10^{5} \mu \mathrm{m}^{2}$ surface area (estimated from the RC time constant) of the $\mathrm{P}$ cell in culture. Assuming no change in $\mathrm{Cl}$ channel properties and that 5-HT released by the Retzius cell acts only at synaptic sites, this suggests a 1000-fold increase in the density of subsynaptic $\mathrm{Cl}$ channels. Since highdensity clustering of subsynaptic receptors is well known in muscle fibers (Fambrough, 1979) and in parasympathetic neu-

A

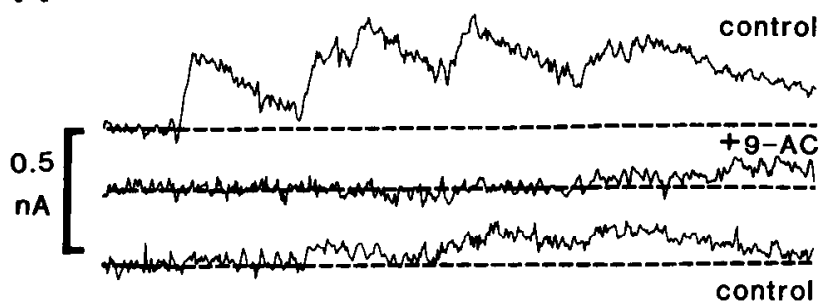

$P$ cell
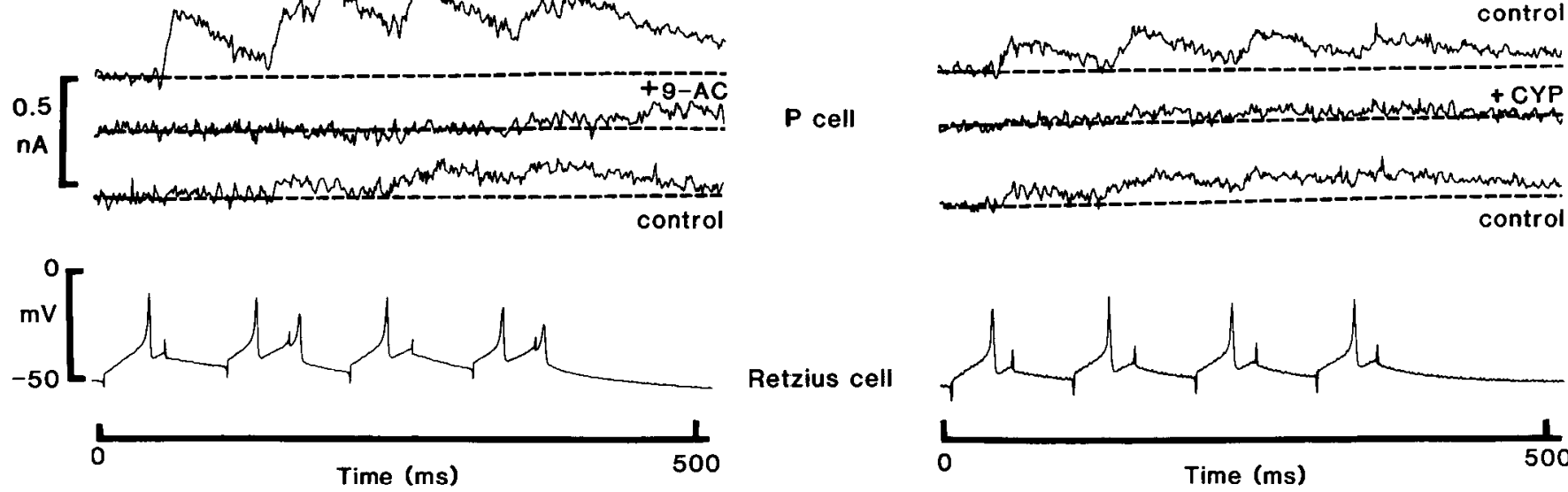

Retzius cell

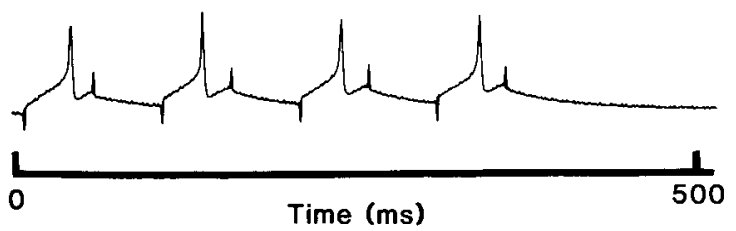

Figure 9. Effects of blockers on the synaptic currents in P cells in culture. Action potentials were triggered in the Retzius cells (bottom recordings in $A$ and $B$, corresponding to the uppermost recordings from the P cells), and synaptic currents were recorded in P cells held at $-20 \mathrm{mV}$. The cells were superfused in normal solution before and after (uppermost and third traces, respectively) superfusion with the same solution containing 9-AC ( $A$, second trace) or CYP $(B$, second trace). 


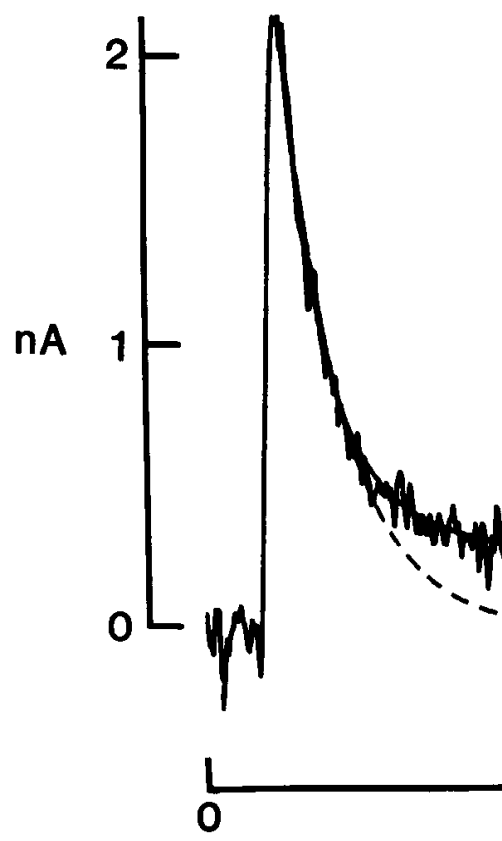

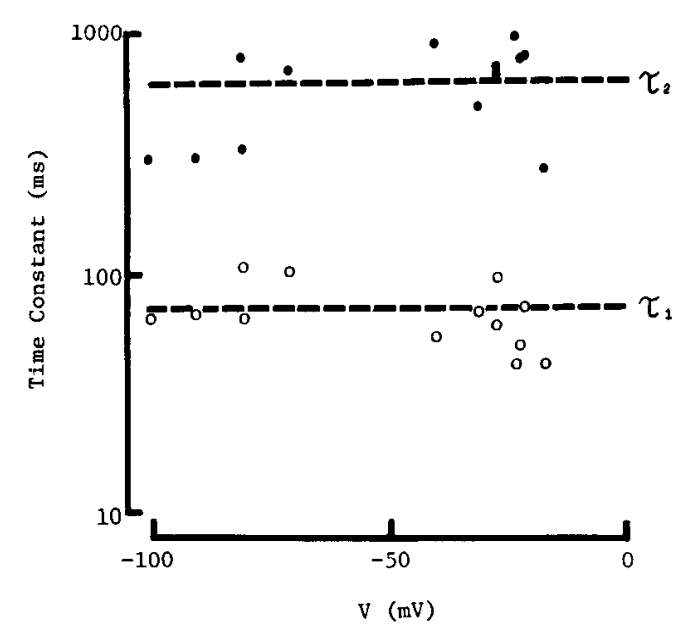

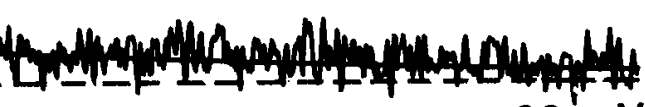

Figure 10. Time course of the decay of the synaptic current in a $\mathrm{P}$ cell in culture. The time course of the decay of the synaptic currents recorded in the same experiment described in Figure 7 were examined as shown for a recording obtained at a holding potential of $-20 \mathrm{mV}$ (the largest response). The broken line is the solution to the monoexponential equation: $I=I_{\max }[1-\exp (-t / 110 \mathrm{msec})]$, where $I_{\max }$ is the difference between the peak current and baseline current $(2.07 \mathrm{nA})$, and the time constant of $110 \mathrm{msec}$ was chosen to fit the data by eye. The solid line is the solution to the biexponential equation: $I=0.85 \times I_{\max }[1-\exp (-t / 72 \mathrm{msec})]+0.15 \times I_{\max }[1-\exp (-t / 797 \mathrm{msec})]$ where $I_{\max }$ is the same as above $(2.07$ $\mathrm{nA}$ ) and the time constants of 72 and $797 \mathrm{msec}$ were determined by regression analysis. Inset, A plot of the first (open circles) and second (filled circles) time constants obtained by regression analysis of the current traces as a function of the holding potential; the lines are the mean values of the first $(69 \mathrm{msec})$ and second $(620 \mathrm{msec})$ time constants.

rons of the frog heart (Harris et al., 1971), our finding with the $\mathrm{P}$ cell would be consistent with a similar redistribution of 5-HT receptors activating $\mathrm{Cl}$ channels following innervation by the Retzius cell.

Following innervation of a P cell by a Retzius cell in culture, application of 5-HT elicited a reduced $g \mathrm{Cl}_{\mathrm{s}}$. This could have been due to a synaptic diffusional barrier to the pulse of 5-HT (as suggested in Results for the slow effect of blockers of the synaptic current), resulting in activation of only extrasynaptic receptors. Accordingly, the sum of $\mathrm{gCl}_{\mathrm{S}}$ (see Fig. 12) activated
A

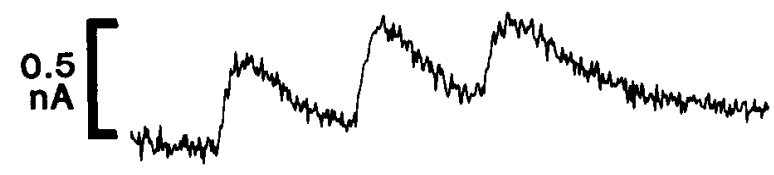

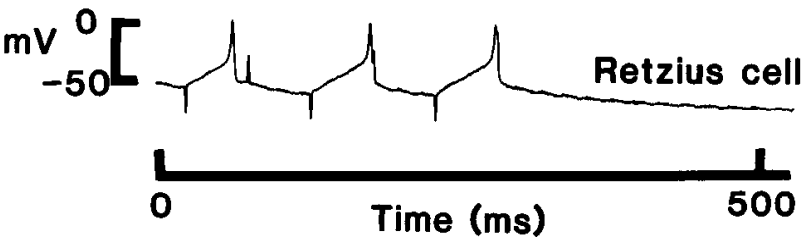

B

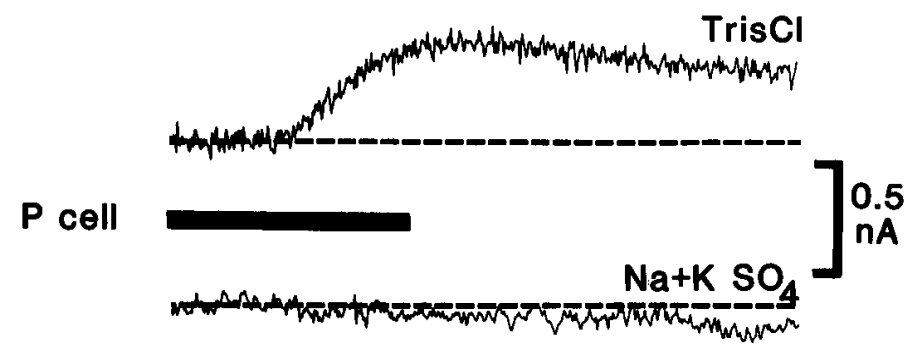

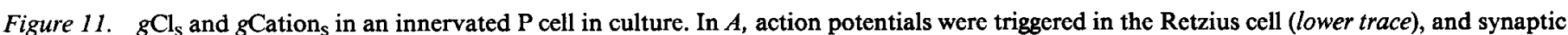
currents were recorded in the P cell (upper trace) clamped at $-20 \mathrm{mV}$ in normal solution. In $B, 5-\mathrm{HT}$ was applied to the P cell, and the current was recorded while the $\mathrm{P}$ cell was superfused with TrisCl solution at $-20 \mathrm{mV}$ (upper trace) or $\mathrm{Na}^{+} \mathrm{K} \mathrm{SO}_{4}$ solution at $-60 \mathrm{mV}$ (lower trace). 

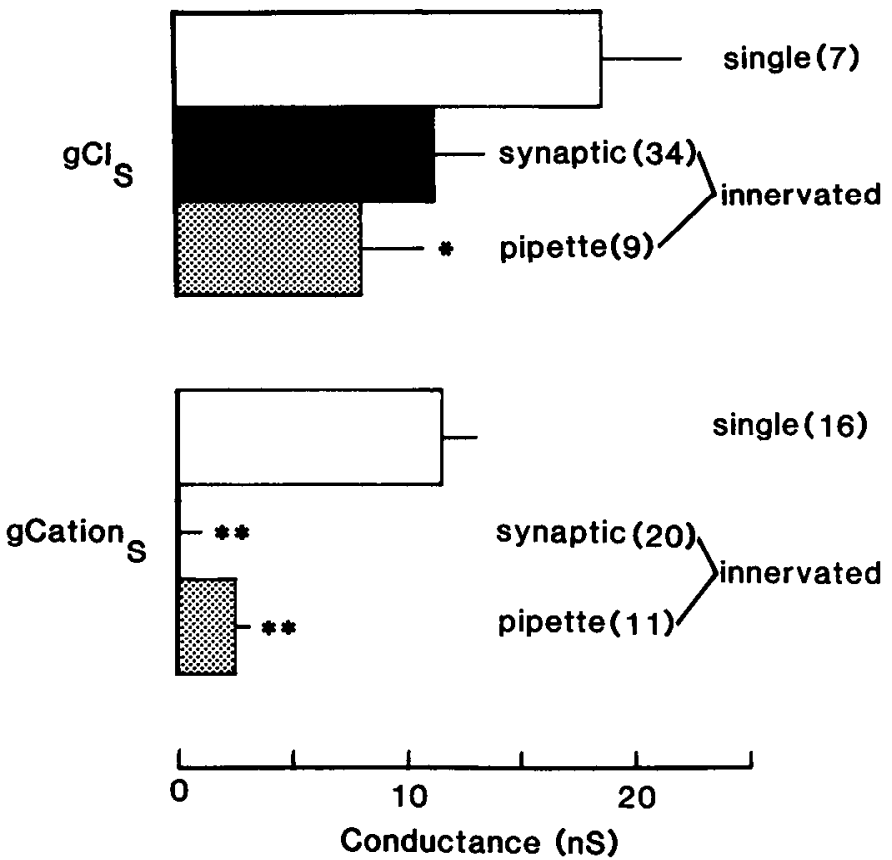

Figure 12. Summary of $g \mathrm{Cl}_{5}$ and $g \mathrm{Cation}_{\mathrm{s}}$ in single and in innervated $P$ cells in culture. $\mathrm{gCl}_{\mathrm{s}}$ (chord conductance at $-20 \mathrm{mV}$; upper histogram)

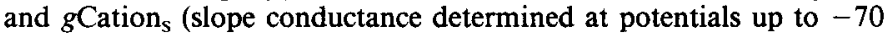
$\mathrm{mV}$; lower histogram) were determined in $\mathrm{P}$ cells superfused in TrisCl or $\mathrm{Na}+\mathrm{K} \mathrm{SO}_{4}$ solution, respectively. The open bars are data for single $P$ cells to which 5-HT was applied, the filled bars are for measurements in innervated $\mathrm{P}$ cells upon synaptic release of 5-HT, and the stippled bars are for 5-HT application onto innervated $\mathrm{P}$ cells. The values in parentheses are the number of determinations. A single asterisk represents $p<0.05$, and double asterisks represent $p<0.01$ for the result of Student's $t$ test analysis of the significance of the difference between the mean of the results indicated and the results with the single $P$ cells.

synaptically $(11.2 \pm 2.1 \mathrm{nS})$ and by applied $5-\mathrm{HT}(8.0 \pm 2.5$ $\mathrm{nS})$ was $19.2 \pm 3.5 \mathrm{nS}$ and is comparable to the value of 19.3 $\pm 4.1 \mathrm{nS}$ obtained for the single $\mathrm{P}$ cell.

Our results clearly demonstrate that it is only $\mathrm{gCl}_{\mathrm{s}}$, and not gCation $_{\mathrm{s}}$, that is activated by synaptic release of 5-HT in culture, consonant with the observation in vivo (Fuchs et al., 1982). We did not determine if the loss of $g$ Cation $_{\mathbf{s}}$ was due to inactivation of the channels following innervation or to exclusion of receptors. A differential distribution of gCation $_{\mathrm{s}}$ has been suggested for the single $P$ cell in culture since the greatest sensitivity of the depolarizing response to 5-HT application is at the base of outgrowing neurites (Pellegrino and Simmoneau, 1984). Our results suggest that the lowest level of gCation $_{\mathrm{s}}$ in $\mathrm{P}$ cells innervated by Retzius cells is at the synaptic sites.

Surprisingly, $g$ Cation $_{\mathrm{s}}$ was reduced at extrasynaptic sites. The elimination of the excitatory response to 5-HT upon innervation appears to be stronger in culture than in vivo, where the response is lost at synaptic sites (Fuchs et al., 1982) but is retained in the (extrasynaptic) P cell soma (Henderson, 1983). Perhaps P cells in the developing nervous system have a much larger gCation $_{5}$ prior to being innervated by the Retzius cell. On the other hand, the loss of $g_{\text {Cation }}$ during development may be localized to sites on the $P$ cell that are postsynaptic to the Retzius cell and amount to a surface area comparable to that of most of the $P$ cell soma in culture.

The modification of the responses to transmitter observed for the $P$ cell demonstrates the remarkable precision with which the neurons reform this specific connection in culture, i.e., to the level of discriminating between different postsynaptic receptors for the same transmitter. It will be of interest in future experiments to determine the contributions of changes in receptor properties, distribution, and turnover in bringing about the selection of both receptor subtypes. However, more than the choice of receptor types is involved after appropriate neurons have come into contact. This is strikingly illustrated by the observation that when confronted with the same target cells in culture, 2 branches of the axon of a single identified Aplysia neuron have different capacities to reform synapses (Schacher, 1985). Another example is the preferential formation of cholinergic synapses by an identified Aplysia neuron in culture with its normal targets compared with other postsynaptic neurons possessing $\mathrm{ACh}$ receptors (Camardo et al., 1983). These model culture preparations appear useful for characterizing synapse formation at a cellular level.

\section{References}

Bixby, J. L., and N. C. Spitzer (1982) The appearance and development of chemosensitivity in Rohon-Beard neurones of the Xenopus spinal cord. J. Physiol. (Lond.) 330: 513-536.

Bryant, S. H., and A. Morales-Aguilera (1971) Chloride conductance in normal and myotonic muscle fibres and the action of monocarboxylic aromatic acids. J. Physiol. (Lond.) 219: 367-383.

Camardo, J., E. Proshansky, and S. Schacher (1983) Identified Aplysia neurons form specific chemical synapses in culture. J. Neurosci. 3: 2614-2620.

Dietzel, I. D., P. Drapeau, and J. G. Nicholls (1986) Voltage dependence of 5-hydroxytryptamine release at a synapse between identified leech neurones in culture. J. Physiol. (Lond.) 372: 191-205.

Drapeau, P., and S. Sanchez-Armass (1987) Synaptic and total currents activated by serotonin at a synapse between identified neurons in culture. Biophys. J. 51: 63a (abstr.).

Fambrough, D. M. (1979) Control of acetylcholine receptors in skeletal muscle. Physiol. Rev. 59: 165-227.

Fuchs, P., J. G. Nicholls, and D. F. Ready (1981) Membrane properties and selective connexions of identified leech neurones in culture. $J$. Physiol. (Lond.) 316: 203-223.

Fuchs, P. A., L. P. Henderson, and J. G. Nicholls (1982) Chemical transmission between individual Retzius and sensory neurones of the leech in culture. J. Physiol. (Lond.) 323: 195-210.

Gerschenfeld, H. M. (1973) Chemical transmission in invertebrate central nervous systems and neuromuscular junctions. Physiol. Rev. 53: $1-119$

Gerschenfeld, H. M., and D. Paupardin-Tritsch (1974) On the transmitter function of 5-hydroxytryptamine at excitatory and inhibitory monosynaptic junctions. J. Physiol. (Lond.) 243: 457-481.

Goldman, D. E. (1943) Potential, impedance and rectification in membranes. J. Gen. Physiol. 27: 37-60.

Goodman, C. S., and N. C. Spitzer (1979) Embryonic development of identified neurones: Differentiation from neuroblast to neurone. Nature 280: 208-214.

Harris, A. J., S. W. Kuffler, and M. J. Dennis (1971) Differential chemosensitivity of synaptic and extrasynaptic areas on the neuronal surface membrane in parasympathetic neurons of the frog, tested by microapplication of acetylcholine. Proc. R. Soc. London [Biol.] 177: 541-553.

Henderson, L. P. (1983) The role of 5-hydroxytryptamine as a transmitter between identified leech neurones in culture. J. Physiol. (Lond.) 339: 309-324.

Hillc, B. (1984) Ionic Channels in Excitable Membranes, Sinauer, Sunderland, MA.

Hodgkin, A. L., and B. Katz (1949) The effect of sodium ions on the electrical activity of the giant axon of the squid. J. Physiol. (Lond.) 108: $37-77$

Knauf, P. A., and A. J. Rothstein (1971) Chemical modification of membranes. 1. Effects of sulfhydryl and amino reactive reagents on anion and cation permeability of the human red blood cell. J. Gen. Physiol. 58: 190-210.

Kuffler, D. P., J. G. Nicholls, and P. Drapeau (1987) Transmitter localization and vesicle turnover at a serotoninergic synapse between identified leech neurons in culture. J. Comp. Neurol. 256: 516-526. 
Nicholls, J. G. (1987) The search for connections: Studies of regeneration in the nervous system of the leech. Magnes Lecture Series, Vol. 2, pp. 1-86.

Pellegrino, M., and M. Simmoneau (1984) Distribution of receptors for acetylcholine and 5-hydroxytryptamine on identified leech neurones growing in culture. J. Physiol. (Lond.) 352: 669-684.

Ready, D. F., and J. G. Nicholls (1979) Identified neurones isolated from leech CNS make selective connections in culture. Nature 281: $67-68$.
Sawada, M., and R. E. Coggeshall (1976) Ionic mechanism of 5-hydroxytryptamine induced hyperpolarization and inhibitory junctional potential in body wall muscle cells of Hirudo medicinalis. J. Neurobiol. 7: 63-73.

Schacher, S. (1985) Differential synapse formation and neurite outgrowth at two branches of the metacerebral cell of Aplysia in dissociated cell culture. J. Neurosci. 5: 2028-2034. 